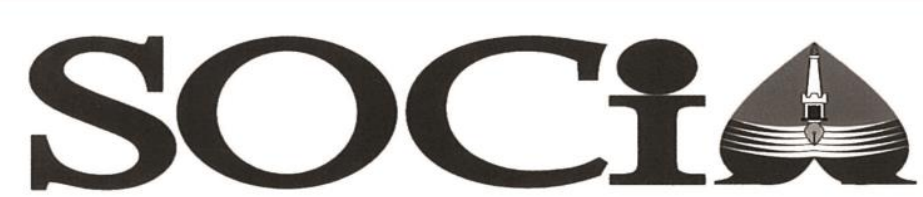

\title{
Pengaruh Kemandirian Belajar dan Ragam Bentuk Tes Terhadap Hasil Belajar Sosiologi
}

\author{
POERWANTI HADI PRATIWI \\ Jurusan Pendidikan Sosiologi FIS UNY \\ pratiwi65@gmail.com
}

\begin{abstract}
Abstrak
Penelitian ini bertujuan untuk menguji ada tidaknya pengaruh kemandirian belajar terhadap hasil belajar Sosiologi, ada tidaknya pengaruh bentuk tes terhadap hasil belajar Sosiologi, dan ada tidaknya interaksi antara kemandirian belajar dan ragam bentuk tes terhadap hasil belajar Sosiologi. Hasil penelitian menunjukkan bahwa: (1) terdapat pengaruh faktor kemandirian belajar terhadap hasil belajar Sosiologi. Rerata skor hasil belajar Sosiologi siswa yang memiliki kemandirian belajar tinggi lebih baik dibandingkan dengan siswa yang memiliki kemandirian belajar sedang dan rendah; (2) terdapat pengaruh faktor bentuk tes terhadap hasil belajar Sosiologi. Rerata skor hasil belajar Sosiologi dengan bentuk tes pilihan ganda biasa lebih besar daripada bentuk tes pilihan ganda analisis kasus; (3) terdapat interaksi antara kemandirian belajar dan bentuk tes terhadap hasil belajar Sosiologi. Artinya, kemandirian belajar dan bentuk tes yang diberikan terbukti berinteraksi secara nyata sehingga memberi pengaruh yang besar terhadap hasil belajar Sosiologi yang diperoleh siswa.
\end{abstract}

Kata kunci: kemandirian belajar, ragam bentuk tes, hasil belajar Sosiologi

\section{Abstract}

This study aims to test the influence of independent learning on learning outcomes of Sociology, presence or absence of the influence of the test on the learning outcomes of Sociology, and the presence or absence of interactions between independent learning and various forms of tests on learning outcomes of Sociology. The results showed that: (1) there is the influence of independent learning on learning outcomes of Sociology. The mean score of Sociology student learning outcomes that have a high learning independence better than students who have learning independence medium and low, (2) there are significant form factor tests on learning outcomes Sociology. The mean score of the learning outcomes of Sociology with the usual form of a multiple choice test is greater than the form of multiple-choice test case analysis, (3) there is an interaction between independent learning and test forms on learning outcomes of Sociology. That is, independent learning and forms of a given test proved significantly interact so as to give a great influence on the results obtained by students studying Sociology.

Keywords: learning independence, various forms of the test, the results of studying Sociology 



\section{PENDAHULUAN}

Kualitas pembelajaran dapat dilihat dari berbagai aspek yang bersifat intern maupun ekstern. Secara khusus, kualitas pembelajaran seringkali dilihat dari dua sisi yaitu proses belajar dan hasil belajar. Proses belajar menekankan pada aktivitas yang dilakukan oleh siswa selama mengikuti pelajaran dan strategi pembelajaran yang diterapkan oleh guru untuk mencapai tujuan pembelajaran yang diharapkan. Sedangkan hasil belajar lebih mencerminkan pada tingkat penguasaan suatu pengetahuan yang dicapai oleh siswa dalam mengikuti program belajar mengajar sesuai dengan tujuan yang ditetapkan.

Tujuan pembelajaran merupakan suatu deskripsi mengenai tingkah laku yang diharapkan dapat dicapai oleh siswa setelah berlangsungnya pembelajaran. Seperti dijelaskan oleh Hamalik (2008: 109) tujuan pembelajaran paling tidak harus mengandung tiga komponen, yaitu: (a) tingkah laku (behavior), digunakan untuk menentukan spesifikasi yang akan diamati dan akan diukur, (b) standar (standard), memungkinkan untuk menilai dampak dari luar, dan (c) kondisi luar (external conditions), untuk meyakinkan bahwa perilaku yang diperoleh benar-benar disebabkan oleh kegiatan belajar, bukan karena penyebab lainnya. Untuk mengetahui apakah tujuan pembelajaran sudah tercapai sesuai dengan komponenkomponen yang telah disebutkan di atas, biasanya guru melakukan penilaian hasil belajar di tingkat kelas sesuai dengan mata pelajaran yang diajarkan.

Penilaian hasil belajar pada hakikatnya merupakan suatu kegiatan untuk mengukur perubahan perilaku yang telah terjadi pada diri siswa. Pada umumnya, hasil belajar akan memberikan pengaruh dalam dua bentuk: (a) siswa akan mempunyai perspektif terhadap kekuatan dan kelemahannya atas perilaku yang diinginkan, (b) perilaku yang 
inginkan itu telah meningkat baik setahap atau dua tahap sehingga timbul lagi kesenjangan antara penampilan perilaku yang sekarang dengan perilaku yang diinginkan (Mulyasa, 2010: 208). Untuk dapat memberikan penilaian hasil belajar tiap siswa, maka perlu dilakukan beberapa kali pengukuran.

Tes dalam dunia pendidikan dipandang sebagai salah satu alat pengukuran. Oleh karena itu, dalam penyusunan tes melibatkan aturan-aturan (seperti petunjuk pelaksanaan dan kriteria penskoran) untuk menetapkan bilangan-bilangan yang menggambarkan kemampuan seseorang. Selanjutnya bilangan tersebut dapat ditafsirkan sebagai pencerminan karakteristik peserta tes. Dalam hal ini tes yang dimaksud adalah tes yang mengukur prestasi (achievement test). Tes prestasi biasanya didesain untuk mengukur pengetahuan atau keterampilan seorang individu pada suatu materi yang telah dipelajari atau diajarkan. Dengan kata lain, tes prestasi lebih berkaitan dengan suatu program spesifik dari suatu tujuan pembelajaran.

Seseorang akan mengalami perubahan perilaku dalam bentuk pengetahuan, keterampilan nilai, dan sikap tertentu melalui proses belajar. Perubahan perilaku yang terjadi merupakan akibat dari proses pembelajaran pada diri seseorang. Proses yang dimaksud adalah aktivitas yang dilakukan individu dalam mencapai tujuan pembelajaran. Pencapaian tujuan pembelajaran itu kemudian dapat dinyatakan sebagai hasil belajar. Setiap siswa memiliki strategi belajar yang berbeda-beda untuk mencapai hasil belajar yang diinginkan. Untuk itulah dituntut kemandirian belajar yang besar pada diri siswa.

Dalam kemandirian belajar, inisiatif merupakan indikator yang sangat mendasar. Surya (2007:157) menjelaskan, belajar mandiri adalah proses menggerakkan kekuatan atau dorongan dari dalam diri individu 
yang belajar untuk menggerakan potensi dirinya mempelajari objek belajar tanpa ada tekanan atau pengaruh asing di luar dirinya. Dengan demikian belajar mandiri lebih mengarah pada pembentukan kemandirian dalam cara-cara belajar. Dalam pengertiannya yang lebih luas, kemandirian belajar mendeskripsikan sebuah proses di mana individu mengambil inisiatif sendiri, dengan atau tanpa bantuan orang lain, untuk mendiagnosis kebutuhan belajar, memformulasikan tujuan belajar, mengidentifikasi sumber belajar, memilih dan menentukan pendekatan strategi belajar, dan melakukan evaluasi hasil belajar yang dicapai.

Kondisi yang diduga sebagai salah satu penyebab rendahnya kualitas pembelajaran yang dilihat dari sisi hasil belajar adalah ketidakmampuan siswa dalam menguasai tujuan pembelajaran. Tujuan pembelajaran yang kemudian diukur melalui soal-soal tes seringkali tidak sesuai dengan apa yang seharusnya dikuasai siswa.

$$
\text { Dalam mata pelajaran }
$$

Sosiologi khususnya, soal-soal tes yang biasa diberikan kepada siswa bila berpatokan pada klasifikasi taksonomi tujuan pendidikan yang dikembangkan oleh Benyamin S. Bloom baru sebatas aspek kognitif tipe C1 (pengetahuan) dan C2 (pemahaman). Padahal jika mencermati standar isi KTSP (Kurikulum Tingkat Satuan Pendidikan) mata pelajaran Sosiologi yang dikeluarkan BSNP (Badan Standar Nasional Pendidikan) maka soal-soal tes bisa mencapai C3 sampai dengan C6, meskipun sama-sama bertipe pilihan ganda. Seringnya siswa menjalani tes dengan tipe soal pilihan ganda C1 dan C2 dapat menjadi penyebab rendahnya kemandirian belajar. Soal bertipe ini memungkinkan siswa untuk asal menebak saja tanpa perlu mengandalkan kemampuan berpikir kritis dan analitis yang menjadi salah satu ciri dari belajar mandiri. Kemampuan berpikir 
kritis dan analitis tentunya dimiliki apabila siswa terbiasa mencari dan menghubungkan pengetahuan yang didapatkan di sekolah dengan pengetahuan baru yang diperoleh dari sumber-sumber belajar yang lain. Diduga bahwa kemandirian belajar merupakan salah satu indikator keberhasilan belajar siswa.

Selanjutnya, salah satu alat ukur yang digunakan untuk menentukan kualitas hasil belajar dan sekaligus mendorong aktivitas belajar siswa adalah evaluasi formatif (yang digunakan dalam penelitian ini adalah butir soal objektif, meliputi: tipe pilihan ganda biasa dan pilihan ganda analisis kasus). Pada penelitian eksperimen yang dilakukan ini menggunakan ragam bentuk tes objektif tipe pilihan ganda biasa dan pilihan ganda analisis kasus. Dasar pertimbangan memilih bentuk tes ini karena dapat dipergunakan untuk mengukur kemampuan ingatan, pemahaman, dan penerapan yang lebih kompleks. Bentuk tes ini juga dapat digunakan untuk mengukur kemampuan siswa yang lebih tinggi dan dapat diskor secara objektif. Pemilihan pada tipe (pilihan ganda biasa) dikarenakan guru-guru sekolah yang menggunakan butir tes ini ternyata "cukup sering" atau "sangat sering", sesuai dengan hasil penelitian Asmin (2006: 639). Sedangkan tipe pilihan ganda analisis kasus digunakan agar dapat mengakomodir sifat dari disiplin ilmu Sosiologi itu sendiri; di mana pembelajaran Sosiologi di tingkat Sekolah Menengah Atas (SMA) ditujukan untuk mengembangkan kemampuan pemahaman fenomena kehidupan sehari-hari.

Semakin sering evaluasi formatif dilakukan dalam proses pembelajaran, semakin meningkat pula hasil belajar siswa. Dijelaskan pula oleh Saifuddin Azwar (2007: 9) bahwa "hasil tes prestasi formatif dapat menyebabkan perubahan kebijaksanaan mengajar atau belajar, apabila perlu". Pengujian yang dilakukan 
berulang kali juga dapat memberi informasi penting bagi guru, terutama dalam hal membantu memusatkan pembelajaran dan memberi bukti pemahaman siswa. Untuk membuat pertimbangan yang valid dan reliabel tentang tingkat prestasi siswa, maka guru harus menggunakan berbagai bukti yang berbeda dalam konteks yang diukur. Berbagai permasalahan di atas kiranya menarik untuk ditindak lanjuti dalam kerangka penelitian quasieksperimen tentang pengaruh ragam bentuk tes objektif dan kemandirian belajar terhadap hasil belajar Sosiologi siswa Sekolah Menengah Atas (SMA).

\section{METODE}

Penelitian ini termasuk penelitian eksperimen semu (quasi-experimental research), dengan menggunakan 2 x 3 faktorial desain. Alasannya karena melibatkan dua atau lebih faktor (variabel) di mana dari setiap variabelnya terdapat sejumlah kategori perlakuan (level faktor).
Untuk analisis variansi dua arah pada setiap pertemuan perlakuan dua faktornya akan diperoleh sel kombinasi kategori (Anonim, 2010: 50).

Dalam desain ini, variabel terikat adalah hasil belajar siswa dalam mata pelajaran Sosiologi, variabel eksperimen adalah tes objektif yang terdiri atas tipe pilihan ganda analisis kasus dan tipe pilihan ganda biasa, dan variabel atribut adalah kemandirian belajar siswa yang terdiri atas tiga level yaitu kemandirian tinggi, kemandirian sedang, dan kemandirian rendah.

Tabel 1. Desain Faktorial 2 × 3

\begin{tabular}{|c|c|c|}
\hline \multirow[b]{2}{*}{$\begin{array}{c}\text { Kemandirian } \\
\text { Belajar }\end{array}$} & \multicolumn{2}{|c|}{$\begin{array}{c}\text { Ragam Bentuk } \\
\text { Tes Objektif }\end{array}$} \\
\hline & $\begin{array}{c}\text { Pilihan } \\
\text { Ganda } \\
\text { Biasa } \\
\left(B_{1}\right)\end{array}$ & $\begin{array}{c}\text { Pilihan } \\
\text { Ganda } \\
\text { Analisis } \\
\text { Kasus } \\
\left(\mathrm{B}_{2}\right)\end{array}$ \\
\hline Tinggi $\left(A_{1}\right)$ & $\mathrm{A}_{1} \mathrm{~B}_{1}$ & $\mathrm{~A}_{1} \mathrm{~B}_{2}$ \\
\hline Sedang $\left(A_{2}\right)$ & $\mathrm{A}_{2} \mathrm{~B}_{1}$ & $\mathrm{~A}_{2} \mathrm{~B}_{2}$ \\
\hline Rendah $\left(\mathrm{A}_{3}\right)$ & $\mathrm{A}_{3} \mathrm{~B}_{1}$ & $\mathrm{~A}_{3} \mathrm{~B}_{2}$ \\
\hline
\end{tabular}

Keterangan:

$\mathrm{A}_{1} \mathrm{~B}_{1}=$ Kelompok siswa yang memiliki kemandirian belajar 
tinggi yang dites dengan tes pilihan ganda biasa

$\mathrm{A}_{1} \mathrm{~B}_{2}=$ Kelompok siswa yang memiliki kemandirian belajar tinggi yang dites dengan tes pilihan ganda analisis kasus

$\mathrm{A}_{2} \mathrm{~B}_{1}=$ Kelompok siswa yang memiliki kemandirian belajar sedang yang dites dengan tes pilihan ganda biasa

$\mathrm{A}_{2} \mathrm{~B}_{2}=$ Kelompok siswa yang memiliki kemandirian belajar sedang yang dites dengan tes pilihan ganda analisis kasus

$\mathrm{A}_{3} \mathrm{~B}_{1}=$ Kelompok siswa yang memiliki kemandirian belajar rendah yang dites dengan tes pilihan ganda biasa

$\mathrm{A}_{3} \mathrm{~B}_{2}=$ Kelompok siswa yang memiliki kemandirian belajar rendah yang dites dengan tes pilihan ganda analisis kasus

Populasi penelitian adalah siswa kelas XI SMA di SMAN 2 Banguntapan Bantul Tahun Pelajaran 2012/ 2013. Pengambilan sampel dilakukan secara acak bertahap (multistage random sampling). Secara berturut-turut dilakukan dengan cara: (a) menetapkan dua kelas yang memiliki karakteristik setara, yaitu kelas XI-1 dan kelas XI-3; (b) memilih secara acak siswa yang akan digunakan sebagai sampel penelitian pada dua kelas terpilih, kelas XI-1 sebanyak 24 siswa dan kelas XI-3 sebanyak 24 siswa; (c) untuk mengelompokkan siswa sesuai dengan tingkat kemandiriannya, maka dilakukan pengukuran kemandirian belajar siswa; (d) mengelompokkan sampel terpilih pada setiap sel sesuai dengan desain penelitian.

Teknik pengumpulan data yang digunakan adalah tes dan angket. Tes digunakan untuk mendapatkan data hasil belajar siswa disusun dengan bentuk objektif menggunakan tipe pilihan ganda analisis kasus dan tipe pilihan ganda biasa. Angket digunakan untuk mendapatkan data tentang kemandirian siswa dalam pembelajaran Sosiologi. Data yang bersumber dari angket dikumpulkan pada tahap awal agar segera diketahui tingkat/ level kemandirian siswa, untuk kemudian dikelompokkan sesuai dengan desain penelitian yang telah ditentukan.

Instrumen yang digunakan dalam penelitian ini ada dua jenis, yaitu instrumen untuk mengukur hasil belajar siswa menggunakan 
tes dan instrumen untuk reliabilitas yang memenuhi mengukur sikap kemandirian kriteria.

belajar siswa menggunakan

Analisis data menggunakan angket. Tes objektif yang statatistik deskriptif, program dikembangkan peneliti disesuaikan dengan pokok bahasan atau sub bahasan dari kompetensi dasar terpilih yang ada dalam Standar Isi KTSP (Kurikulum Tingkat Satuan Pendidikan) Mata Pelajaran Sosiologi yang dikeluarkan oleh BSNP (Badan Standar Nasional Pendidikan). Angket kemandirian belajar disusun menggunakan indikator-indikator yang dikemukakan oleh Guglielmino, West \& Bentley (lewat Sugilar, 2000: 13), meliputi: (1) kecintaan terhadap belajar, (2) kepercayaan diri sebagai siswa, (3) keterbukaan terhadap tantangan belajar, (4) sifat ingin tahu, (5) pemahaman diri dalam hal belajar, dan (6) menerima tanggung jawab untuk kegiatan belajarnya. Dimana sebelumnya telah divalidasi dan diuji cobakan sehingga sudah menggambarkan bobot nilai skala tetap, validitas butir, dan SPSS dan program EXCEL untuk mengolah rerata, median, modus, simpangan baku, dan varians. Uji prasyarat meliputi uji asumsi normalitas dan homogenitas varians. Normalitas data diuji dengan menggunakan uji Kolmogorov-Smirnov dengan koreksi Lilliefors, sedangkan homogenitas varians diuji dengan menggunakan Levene's Test. Prosedur pengujian hipotesis dilakukan dengan ANAVA (analisis varians) dua arah dengan desain faktorial $2 \times 3$, taraf signifikasi 5\%. Teknik anava 2 arah dapat digunakan untuk menguji perbedaan dua mean atau lebih. Apabila hasil uji anava menunjukkan $\mathrm{H}_{\mathrm{o}}$ ditolak sehingga $\mathrm{H}_{1}$ diterima artinya masing-masing variabel memiliki pengaruh, maka perlu dilakukan uji lanjutan untuk memastikan variabel mana yang memiliki pengaruh dengan signifikansi paling kuat. Untuk 
mengujinya diperlukan uji Klasifikasi Kemandirian Belajar komparasi atau perbandingan. Dalam penelitian ini digunakan uji komparasi metode Tukey untuk mencari tipe atau kelompok mana saja yang berbeda dan mana yang sama.

\section{HASIL DAN PEMBAHASAN}

\section{Hasil Analisis Data}

Berdasarkan hasil penelitian diperoleh data tentang kemandirian belajar siswa yang didasarkan pada distribusi normal, dibagi menjadi tiga klasifikasi, yaitu tinggi (T), sedang (S), dan rendah (R). Hasil perhitungan skor kemandirian belajar siswa terlihat dari output SPSS di bawah ini.

\begin{tabular}{c|l}
\multicolumn{2}{c}{ Siswa } \\
\hline Klasifikasi & \multicolumn{1}{c}{ Interval } \\
\hline Kelas XI.1 & \multicolumn{1}{c}{$\begin{array}{l}\text { x }>\mathrm{M}+1 \mathrm{SD} \\
=\mathrm{x}>113.637\end{array}$} \\
\hline Tinggi & $\mathrm{M}-1 \mathrm{SD} \leq \mathrm{x} \leq \mathrm{M}+1$ \\
& $\begin{array}{l}\mathrm{SD}=60.445 \leq \mathrm{x} \leq \\
113.637\end{array}$ \\
\hline Redang & $\mathrm{x}<\mathrm{M}-1 \mathrm{SD}$ \\
$=\mathrm{x}<60.445$
\end{tabular}

\begin{tabular}{c|l}
\hline \multicolumn{2}{l|}{ Kelas XI.3 } \\
\hline Tinggi & $\mathrm{x}>\mathrm{M}+1 \mathrm{SD}$ \\
& $=\mathrm{x}>114.520$ \\
\hline Sedang & $\mathrm{M}-1 \mathrm{SD} \leq \mathrm{x} \leq \mathrm{M}+1$ \\
& $\begin{array}{l}\mathrm{SD}=62.396 \leq \mathrm{x} \leq \\
114.520\end{array}$ \\
\hline Rendah & $\mathrm{x}<\mathrm{M}-1 \mathrm{SD}$ \\
& $=\mathrm{x}<62.396$ \\
\hline
\end{tabular}

Berdasarkan

tabel

\begin{tabular}{|c|c|c|c|c|c|c|c|}
\hline & $\mathrm{N}$ & Range & Minimum & Maximum & Mean & Std Deviation & \\
\hline kelasXI.1 & 24 & 71.00 & 47.00 & 118.00 & 87.0417 & 26.59598 & \\
\hline $\begin{array}{l}\text { kelasXl.3 } \\
\text { Valid N(listwise) }\end{array}$ & 24 & 73.00 & 47.00 & 120.00 & 88.4583 & 26.06176 & s maka \\
\hline
\end{tabular}

Selanjutnya, hasil perhitungan tersebut diolah untuk mendapatkan interval skor siswa yang memiliki kemandirian belajar tinggi, sedang, dan rendah; seperti terlihat pada tabel berikut.

Tabel 2 terpilih pada setiap sel sesuai dengan desain penelitian. Ringkasan data skor hasil belajar yang bersumber dari kemandirian belajar dan bentuk tes pada setiap sel dalam desain penelitian dapat dilihat pada tabel di bawah ini.

Tabel 3. 
Ringkasan Data Skor Hasil Belajar

\begin{tabular}{|c|c|c|c|}
\hline 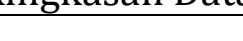 & & \multicolumn{2}{|c|}{ B } \\
\hline \multicolumn{2}{|c|}{ A } & $\mathrm{B}_{1}$ & Depenaent \\
\hline \multirow{3}{*}{$\mathrm{A}_{1}$} & $X_{h b}$ & 38.333 & es \\
\hline & $S D$ & 1.032 & Pilihan \\
\hline & $\mathrm{N}$ & 6 & Ganda \\
\hline \multirow{3}{*}{$\mathrm{A}_{2}$} & $X_{h b}$ & 32.50 & \\
\hline & $S D$ & 1.643 & Pilihan \\
\hline & $\mathrm{N}$ & 6 & Ganda \\
\hline \multirow{3}{*}{$\mathrm{A}_{3}$} & $X_{h b}$ & 22.33 & Kasus \\
\hline & $S D$ & 1.211 & Total \\
\hline & $\mathrm{N}$ & 6 & \\
\hline
\end{tabular}

Tabel 4.

Descriptive Statistics

Descriptive

\begin{tabular}{|c|r|r|r}
\hline Kemandirian_Belajar & Mean & $\begin{array}{c}\text { Std. } \\
\text { Deviation }\end{array}$ & N \\
\hline Tinggi & 38.3333 & 1.03280 & 6 \\
Sedang & 32.5000 & 1.64317 & 6 \\
Rendah & 22.3333 & 1.21106 & 6 \\
Total & 31.0556 & 6.91522 & 18 \\
Tinggi & 22.3333 & 1.21106 & 6 \\
Sedang & 15.0000 & 3.40588 & 6 \\
Rendah & 6.3333 & .81650 & 6 \\
Total & 14.5556 & 7.02284 & 18 \\
Tinggi & 30.3333 & 8.42435 & 12 \\
Sedang & 23.7500 & 9.48803 & 12 \\
Rendah & 14.3333 & 8.41355 & 12 \\
Total & 22.8056 & 10.82542 & 36
\end{tabular}

\section{Keterangan:}

$\mathrm{X}_{\mathrm{hb}} \quad=$ Rerata skor hasil belajar

SD = Simpangan baku skor hasil belajar

$\mathrm{n} \quad=$ Banyaknya skor hasil belajar

$\mathrm{A}_{1}=$ Kelompok siswa yang memiliki kemandirian belajar tinggi

$\mathrm{A}_{2}=$ Kelompok siswa yang memiliki kemandirian belajar sedang

$\mathrm{A}_{3}=$ Kelompok siswa yang memiliki kemandirian belajar rendah

$\mathrm{B}_{1}=$ Bentuk tes pilihan ganda biasa

$\mathrm{B}_{2}=$ Bentuk tes pilihan ganda analisis kasus

Untuk pengujian hipotesis

digunakan hasil analisis data dengan program SPSS berupa hasil ANAVA dua arah yang dapat dilihat pada tabel 4, tabel 5, dan tabel 6 .
Tabel Descriptive Statistics di atas menggambarkan rata-rata dan standar deviation hasil belajar dan kemandirian belajar. Untuk tes pilihan ganda biasa rata-rata hasil belajar lebih besar dari pada tes pilihan ganda analisis kasus. Tes pilihan ganda biasa rata-rata hasil belajar sebesar 38.33 sedangkan tes pilihan ganda analisis kasus rata-rata hasil belajar sebesar 22.33 untuk siswa tipe kemandirian belajar tinggi.

Tabel 5.

Rangkuman ANAVA Skor Hasil Belajar Tests of Between-Subjects Effects

Dependent Variable:Hasil_Belajar 


\begin{tabular}{|c|c|c|c|c|c|c|}
\hline Source & $\begin{array}{l}\text { Type III } \\
\text { Sum of } \\
\text { Squares }\end{array}$ & Df & $\begin{array}{l}\text { Mean } \\
\text { Square }\end{array}$ & $\mathrm{F}$ & $\begin{array}{l}\text { eman } \\
\text { Sig. }\end{array}$ & $\begin{array}{l}\text { dirian belajar (tinggi, } \\
\text {, rendah). }\end{array}$ \\
\hline $\begin{array}{l}\text { Corrected } \\
\text { Model }\end{array}$ & $4006.806^{a}$ & 5 & 801.361 & 253.506 & $\begin{array}{r}.000 \\
\text { erbe }\end{array}$ & $\begin{array}{l}\text { Jntuk melihat apakah ada } \\
\text { daan hasil belajar dari faktor }\end{array}$ \\
\hline Intercept & 18723.361 & 1 & 18723.361 & 5923.032 & perita & k soal dengan kemandirian \\
\hline Bentuk_Tes & 2450.250 & 1 & 2450.250 & 775.123 & .000 & c danat dilihat nada $n$-vals \\
\hline $\begin{array}{l}\text { Kemandirian_B } \\
\text { elajar }\end{array}$ & 1552.056 & 2 & 776.028 & 245.492 & yang & dihasilkan. Diketahui bahwa \\
\hline $\begin{array}{l}\text { Bentuk_Tes * } \\
\text { Kemandirian_B } \\
\text { elajar }\end{array}$ & 4.500 & 2 & 2.250 & $.712 \mathrm{I}$ & pentu & $\begin{array}{c}p \text {-value untuk } \\
\text { __Tes* Kemandirian_Belajar }\end{array}$ \\
\hline Error & 94.833 & 30 & 3.161 & & \$ebes & r $0.044(<0.05)$ yang berarti \\
\hline Total & 22825.000 & 36 & & & terdap & perbedaan yang \\
\hline Corrected Total & 4101.639 & 35 & & & & kan antara bentuk tes \\
\hline
\end{tabular}

Effect merupakan tabel yanr Tabel 6.

mempresentasikan hasil hipotes 4 Dependent Variable:Hasil_Belajar

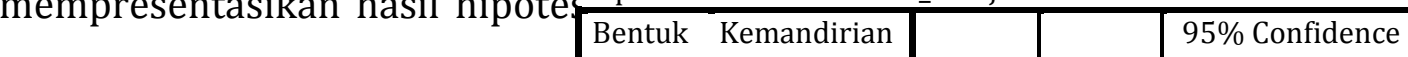

Dapat dilihat nilai $p$-value unt_Tes_Belajar

kategori bentuk soal sebesar 0.0

$(<0.05)$, maka kesimpulanr

\begin{tabular}{lll|l|l|l|l|l|} 
terdapat & perbedaan & ya Biasa & Sedang & 32.500 & .726 & 31.018 & 33.982 \\
\cline { 3 - 7 } & & Rendah & 22.333 & .726 & 20.851 & 23.816 \\
\hline
\end{tabular}

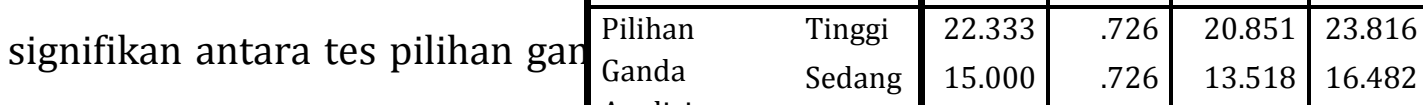

biasa dan tes pilihan ganda anali \begin{tabular}{ll|r|r|r|r} 
Analisis & Rendah & 6.333 & .726 & 4.851 & 7.816 \\
Kasus & & & & &
\end{tabular}

kasus mengenai rata-rata hasil

Tabel berikutnya yaitu tabel belajar.

Untuk kategori tingkat kemandirian belajar nilai $p$-value sebesar $0.000(<0.005)$ dan nilai uji F sebesar 245.492 artinya terdapat perbedaan rata-rata hasil belajar diantara tiga tingkat

Bentuk_Tes*Kemandirian_Belajar

merupakan tabel yang berisi descriptive statistics. Rata-rata hasil belajar siswa dengan kategori kemandirian belajar tinggi mengerjakan bentuk tes pilihan ganda biasa sebesar 38.33. Sedangkan rata-rata hasil belajar 
siswa dengan kemandirian belajar tinggi mengerjakan bentuk tes pilihan ganda analisis kasus sebesar 22.33 .

Untuk uji lanjut, dengan menggunakan metode Tukey dapat dicari tipe atau kategori mana saja yang berbeda dan mana yang sama. Hasil lengkap analisis data dengan program SPSS melalui uji Tukey dapat dilihat pada tabel 7 dan tabel 8.

Tabel 7.

Rangkuman Hasil Uji Lanjut dengan Uji Tukey

\section{Multiple Comparisons}

Hasil_Belajar

Tukey HSD diperoleh interval konfidensi 95\% untuk setiap pasang mean. Jika interval konfidensi tersebut memuat angka nol maka dapat disimpulkan bahwa terdapat perbedaan yang signifikan.

Untuk pasangan kemandirian belajar tinggi dengan sedang diperoleh interval konfidensi $95 \%$ yaitu $4.79 \leq \mu_{1}-\mu_{2}$ $\leq$ 8.37. Karena interval konfidensi tidak melewati angka nol maka dapat disimpulkan bahwa $\mu_{1} \neq \mu_{2}$. Atau karena diperoleh $p$-value 0.000 ( $<0.05$ ) maka $\mathrm{H}_{0}$ ditolak artinya terdapat perbedaan yang

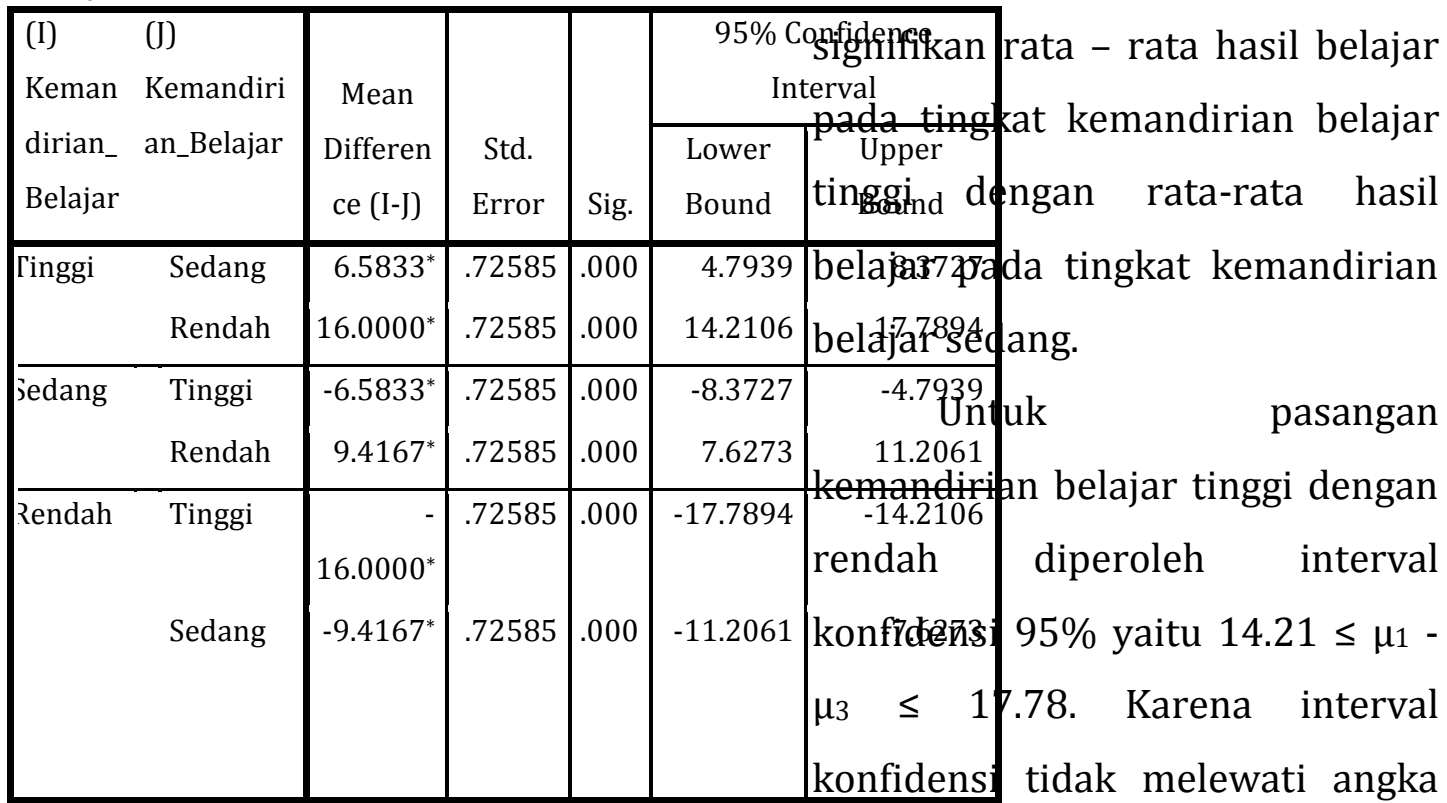
Based on observed means.

*. The mean difference is significant at the .05 level. nol maka dapat disimpulkan Dari tabel Multiple Comparisons di atas dapat bahwa $\mu_{1} \neq \mu_{3}$. Atau karena diperoleh p-value $0.000(<0.05)$ 
maka $\mathrm{H}_{0}$ ditolak artinya terdi perbedaan yang signifikan ra1 rata hasil belajar pada tin̨̧ kemandirian belajar tinggi den rata-rata hasil belajar pada tin kemandirian belajar rendah.

\section{Untuk} pasangan kemandirian belajar sedang dengan rendah diperoleh interval konfidensi 95\% yaitu $7.62 \leq \mu_{2}-\mu_{3}$ $\leq 11.20$. Karena interval konfidensi tidak melewati angka nol maka dapat disimpulkan bahwa $\mu_{2} \neq \mu_{3}$. Atau karena diperoleh p-value 0.000 ( $<0.05)$ maka $\mathrm{H}_{0}$ ditolak artinya terdapat perbedaan yang signifikan rata - rata hasil belajar pada tingkat kemandirian belajar sedang dengan rata-rata hasil belajar pada tingkat kemandirian belajar rendah.

Tabel 8. Hasil Belajar PerKemandirian Belajar
Means for groups in homogeneous subsets are displayed. Based on observed means.

The error term is Mean Square(Error) $=3.161$.

a. Uses Harmonic Mean Sample Size $=12.000$.

b. Alpha $=.05$.

Dari tabel diatas terlihat bahwa kemandirian belajar dengan kategori tinggi, sedang dan rendah berada pada grup yang berbeda, ini berarti terdapat perbedaan rata-rata yang signifikan diantara ketiganya.

Output menunjukkan bahwa tingkat tinggi mempunyai rata-rata 30.33; tingkat sedang mempunyai rata-rata 23.75; dan tingkat rendah mempunyai rata-rata 14.33. Sehingga dapat disimpulkan bahwa $\mu_{1}>\mu_{2}>\mu_{3}$. Atau rata-rata hasil belajar dengan tingkat kemandirian belajar tinggi > sedang $>$ rendah .

\begin{tabular}{|c|c|c|c|c|c|}
\hline \multicolumn{2}{|c|}{ Kemandirian_Belajar } & \multirow[b]{2}{*}{$\mathrm{N}$} & \multicolumn{3}{|c|}{ Subset } \\
\hline & & & 1 & 2 & 3 \\
\hline \multirow{4}{*}{ dimension 1} & Rendah & 12 & 14.3333 & \multirow{3}{*}{23.7500} & \multirow{4}{*}{$\begin{array}{r}30.3333 \\
1.000\end{array}$} \\
\hline & Sedang & 12 & & & \\
\hline & Tinggi & 12 & & & \\
\hline & Sig. & & 1.000 & 1.000 & \\
\hline
\end{tabular}

Pembahasan

\section{Pengaruh Kemandirian}

Belajar terhadap Hasil

Belajar Sosiologi

Pembuktian hipotesis

tentang pengaruh kemandirian belajar terhadap hasil belajar 
Sosiologi dapat dilihat pada tabel 5 yang berisi rangkuman ANAVA skor hasil belajar. Hipotesis penelitian yang menyatakan, "terdapat pengaruh kemandirian belajar terhadap hasil belajar Sosiologi", ternyata secara empiris teruji oleh data. Berdasarkan hasil perhitungan terlihat bahwa hasil statistik uji $p$-value yang diperoleh sebesar 0.00 dengan tingkat signifikansi $\alpha=0.05$. Dengan demikian dapat diambil kesimpulan bahwa Ho ditolak karena $p$-value $=0.000<\alpha=$ 0.05 berarti faktor kemandirian belajar berpengaruh terhadap hasil belajar.

Hal ini dapat terjadi karena pada umumnya siswa yang memiliki kemandirian belajar rendah: (1) kurang inisiatif dalam belajar dan sangat tergantung pada motivasi eksternal, (2) lebih menyukai pembelajaran yang bahan belajarnya telah ditentukan dengan jelas, cara belajarnya juga telah ditentukan dengan jelas. Sangat tergantung pada bimbingan dan penjelasan dari guru, selalu merasa khawatir jika penafsirannya mengenai isi pelajaran kurang tepat, karena itu penjelasan dari guru dirasa sangat penting. Siswa-siswa seperti ini cenderung tidak berusaha sendiri, sebelum meminta bantuan orang lain, (3) belum dapat menilai kemampuan sendiri, lebih menyukai program pembelajaran yang telah mempunyai kriteria keberhasilan yang jelas, sehingga dapat mengarahkan kegiatan belajarnya untuk mencapai kriteria tersebut.

Jika dihubungkan dengan karakteristik bentuk tes yang diberikan adalah tes pilihan ganda analisis kasus memiliki beberapa ciri yang membedakannya dengan tes pilihan ganda biasa. Tes pilihan ganda analisis kasus dapat 


\begin{abstract}
mendorong siswa untuk mengorganisasi gagasan, membandingkan, membedakan, menilai, membuat kesimpulan, mengembangkan solusi pemecahan masalah, menghubungkan prinsip secara konseptual dan menjelaskan hubungan sebab akibat. Meskipun tes bentuk pilihan ganda analisis kasus lebih sulit dibandingkan dengan tes pilihan ganda biasa (yang terlihat dari jumlah skor ratarata yang diperoleh sampel), namun tes ini justru dapat memberikan informasi mengenai kemandirian belajar yang dimiliki siswa sesuai dengan kategori yang telah ditetapkan.
\end{abstract}

Siswa yang memiliki tingkat kemandirian belajar tinggi ternyata juga memperoleh hasil belajar yang lebih baik dibandingkan dengan siswa yang memiliki tingkat kemandirian belajar sedang dan rendah. Dengan demikian, cukup beralasan untuk menerima hipotesis yang menyatakan "terdapat pengaruh kemandirian belajar terhadap hasil belajar Sosiologi”. Yang berarti bahwa tingkat kemandirian belajar rendah, sedang, dan tinggi; ternyata dapat memberikan hasil belajar Sosiologi yang berbeda-beda pula.

\section{Pengaruh Ragam Bentuk Tes terhadap Hasil Belajar Sosiologi}

Pembuktian hipotesis tentang pengaruh ragam bentuk tes terhadap hasil belajar Sosiologi dapat dilihat pada tabel 5 yang berisi rangkuman ANAVA skor hasil belajar. Hipotesis penelitian yang menyatakan, "terdapat pengaruh ragam bentuk tes terhadap hasil belajar Sosiologi", ternyata secara empiris teruji oleh data. Berdasarkan hasil perhitungan terlihat bahwa hasil statistik uji $p$-value yang diperoleh sebesar 0.00 dengan tingkat 
signifikansi $\alpha=0.05$. Dengan demikian dapat diambil kesimpulan bahwa Ho ditolak karena $p$-value $=0.000<\alpha=$ 0.05 berarti faktor bentuk tes berpengaruh terhadap hasil belajar.

Temuan ini dapat dijelaskan lebih lanjut melalui perbandingan karakteristik kedua bentuk tes tersebut. Dilihat dari hasil belajar yang diukur, bentuk tes pilihan ganda biasa sangat efektif untuk mengukur kemampuan kognitif tingkat rendah, efektif untuk mengukur kemampuan kognitif tingkat sedang, dan kurang efektif untuk mengukur kemampuan kognitif tingkat tinggi; sebaliknya, bentuk tes pilihan ganda analisis kasus kurang efektif untuk mengukur kemampuan kognitif rendah, efektif untuk mengukur kemampuan kognitif sedang, dan sangat efektif untuk mengukur kemampuan kognitif tingkat tinggi.
Sesuai dengan karakteristik yang dimiliki mata pelajaran Sosiologi, yaitu dalam belajar Sosiologi harus melibatkan pemikiran secara deduktif dan induktif, kemampuan analisis berdasarkan fenomena yang ada, pengamatan, pola investigasi, serta kemampuan untuk menghubungkan peristiwa-peristiwa yang terjadi di masyarakat; maka karakteristik tersebut sesuai dengan karakteristik yang dimiliki oleh bentuk tes pilihan ganda analisis kasus. Dilihat dari skor rata-rata peserta pada bentuk tes pilihan ganda biasa lebih besar dibandingkan dengan bentuk tes pilihan ganda analisis kasus. Hal ini dapat dipengaruhi oleh kemampuan membaca dan analisis yang dimiliki siswa. Bentuk tes pilihan ganda biasa umumnya hanya mendorong siswa untuk mengingat konsep tertentu saja, sedangkan pada bentuk tes pilihan ganda 
analisis kasus siswa

dihadapkan pada sebuah kasus yang terjadi di masyarakat melalui kutipan artikel media cetak dan media elektronik untuk selanjutnya menafsirkan dan menjawab pertanyaan yang diberikan. Sehingga menjadi sangat penting bagi siswa untuk memiliki kemampuan kognitif tingkat tinggi agar dapat menjawab pertanyaan yang diberikan, daripada hanya sekedar membuat tebakan saja.

Meskipun secara ratarata skor yang diperoleh siswa melalui bentuk tes pilihan ganda biasa lebih tinggi, namun bentuk tes pilihan ganda analisis kasus perlu secara terus menerus dilatihkan dan diberikan kepada siswa agar hasil belajar yang diperoleh siswa benar-benar sesuai dengan tujuan pembelajaran Sosiologi yang diharapkan. Selain itu, kesan bahwa Sosiologi adalah mata pelajaran yang sifatnya hanya hapalan dan teks-book saja dapat diminimalisir melalui evaluasi pembelajaran yang dilakukan guru, khususnya bentuk tes yang diberikan dengan tipe pilihan ganda analisis kasus.

\section{Interaksi}

antara

Kemandirian Belajar dan Ragam Bentuk Tes terhadap Hasil Belajar Sosiologi

Pembuktian hipotesis tentang interaksi antara kemandirian belajar dan ragam bentuk tes terhadap hasil belajar Sosiologi dapat dilihat pada tabel 5 yang berisi rangkuman ANAVA skor hasil belajar. Hipotesis penelitian yang menyatakan, "terdapat interaksi antara kemandirian belajar dan bentuk tes terhadap hasil belajar", ternyata secara empiris teruji oleh data. Berdasarkan hasil perhitungan terlihat bahwa hasil statistik uji p-value yang diperoleh sebesar $\quad 0.044$ dengan tingkat signifikansi $\alpha=$ 0.05. Dengan demikian dapat diambil kesimpulan bahwa Ho 
ditolak karena $p$-value $=0.000$ $<\alpha=0.05$ berarti faktor bentuk tes berpengaruh terhadap hasil belajar.

Untuk melihat lebih rinci interaksi antara bentuk tes dan kemandirian belajar terhadap hasil belajar dapat dilihat pada tabel 7 yang berisi rangkuman hasil uji lanjut dengan uji Tukey yang kemudian dikonsultasikan dengan tabel di bawah ini.

Tabel 9.

Landasan Teori untuk Menentukan Uji Lanjut Hipotesis

\begin{tabular}{|c|c|c|c|c|}
\hline $\begin{array}{c}\text { Uji } \\
\text { Hipotesis }\end{array}$ & $\bar{x}_{i}-\bar{x}_{j}$ & LB & UP & Kesimpulan \\
\hline $\begin{array}{c}\mathrm{Ho}_{0}: \mu_{1}= \\
\mu_{2} \\
\mathrm{H}_{1}: \mu_{1}>\mu_{2}\end{array}$ & + & - & + & $\begin{array}{c}\text { Ho } \\
\text { diterima, } \\
\text { artinya } \\
\mu_{\mathrm{A}}=\mu_{\mathrm{B}}\end{array}$ \\
\hline $\begin{array}{c}\text { Ho: } \mu_{1}= \\
\mu_{3} \\
\mathrm{H}_{1}: \mu_{1}>\mu_{3}\end{array}$ & + & + & + & $\begin{array}{c}\text { Ho ditolak, } \\
\text { artinya } \\
\mu_{\mathrm{A}}>\mu_{\mathrm{C}}\end{array}$ \\
\hline $\begin{array}{c}\text { Ho: } \mu_{2}= \\
\mu_{3} \\
\mathrm{H}_{1}: \mu_{2}<\mu_{3}\end{array}$ & - & + & + & $\begin{array}{c}\text { Ho ditolak, } \\
\text { artinya } \\
\mu_{\mathrm{A}}<\mu_{\mathrm{D}}\end{array}$ \\
\hline
\end{tabular}

melewati nol maka $\mathrm{H}_{0}$ ditolak. Jika $\bar{x}_{\bar{i}}-\bar{x}_{j}>0$ maka $\mu_{1}>\mu_{2}$ dan jika $\bar{x}_{i}-\bar{x}_{j}<0$ maka $\mu_{1}<$ $\mu$ 2. Berdasarkan tabel di atas, maka perhitungan uji hipotesis pada penelitian ini dapat

dirangkum sebagai berikut.

Tabel 10.

Rangkuman Hasil Uji Lanjut

Hipotesis Penelitian

\begin{tabular}{|c|c|c|c|c|}
\hline $\begin{array}{c}\text { Uji } \\
\text { Hipotesis }\end{array}$ & $\bar{x}_{i}-\bar{x}_{j}$ & LB & UP & Kesimpulan \\
\hline $\begin{array}{c}\text { Ho }: \mu_{1}= \\
\mu_{2} \\
\mathrm{H}_{1}: \mu_{1}> \\
\mu_{2}\end{array}$ & 6.58 & 4.79 & 8.37 & $\begin{array}{c}\text { Ho ditolak, } \\
\text { artinya } \\
\mu_{1}>\mu_{2}\end{array}$ \\
\hline $\begin{array}{c}\text { Ho }: \mu_{1}= \\
\mu_{3} \\
\mathrm{H}_{1}: \mu_{1}> \\
\mu_{3}\end{array}$ & 16.00 & 14.21 & 17.78 & $\begin{array}{c}\text { Ho ditolak, } \\
\text { artinya } \\
\mu_{1}>\mu_{3}\end{array}$ \\
\hline $\begin{array}{c}\text { Ho }: \mu_{2}= \\
\mu_{3}\end{array}$ & 9.41 & 7.62 & 11.20 & $\begin{array}{c}\text { Ho ditolak, } \\
\text { artinya } \\
\mathrm{H}_{1}: \mu_{2}>\mu_{3} \\
\mu_{3}\end{array}$
\end{tabular}

Berdasarkan tabel di atas ada tiga hipotesis uji lanjut yang dapat diketahui yaitu:

1) Ho ditolak karena $p_{-}$value $=$ $0.000<\alpha=0.05$, berarti rata - rata hasil belajar pada tingkat kemandirian belajar tinggi tidak sama dengan rata-rata hasil belajar pada tingkat kemandirian belajar sedang.

2) Ho ditolak karena $p_{-}$value = $0.000<\alpha=0.05$, berarti rata - rata hasil belajar pada tingkat kemandirian 
belajar tinggi tidak sama

dengan rata-rata hasil

belajar pda tingkat

Tabel Estimate Marginal

kemandirian belajar

rendah.

3) Ho ditolak karena $p_{-}$value = $0.000<\alpha=0.05$, berarti rata - rata hasil belajar pada tingkat kemandirian belajar sedang tidak sama dengan rata-rata hasil belajar pda tingkat kemandirian belajar rendah.

Hasil perhitungan tersebut juga masih bisa diperjelas dengan tabel hasil output SPSS yang menggambarkan perbedaan pertingkat kemandirian belajar berikut ini.

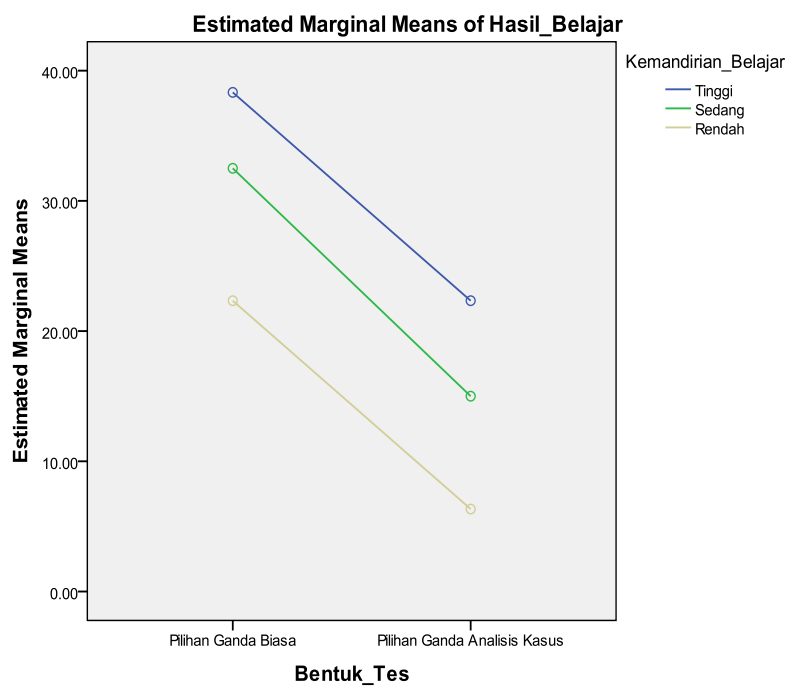

Means of Hasil-Belajar perkemandirian belajar memperjelas hubungan antara bentuk soal dengan kemandirian belajar. Pada gambar di atas terlihat perbedaan yang cukup nyata pada tipe kemandirian tinggi, sedang, rendah untuk bentuk soal mudah dan sulit.

Berdasarkan data-data empiris di atas, hal tersebut dapat terjadi karena bentuk tes pilihan ganda biasa dan pilihan ganda analisis kasus memiliki tingkat keefektifan yang berbeda dalam mengukur hasil belajar mata pelajaran Sosiologi siswa pada tingkat kemandirian belajar yang berbeda. Siswa yang memiliki kemandirian belajar tinggi memperoleh hasil belajar mata pelajaran Sosiologi yang lebih besar pada semua bentuk tes baik pilihan ganda analisis kasus 
maupun pilihan ganda biasa, karena kedua bentuk tes itu memiliki karakteristik yang dapat dijangkau oleh mereka yang memiliki kemandirian belajar yang tinggi.

Bentuk tes pilihan ganda analisis kasus menghendaki siswa untuk melibatkan pemikiran secara deduktif dan induktif, kemampuan analisis berdasarkan fenomena yang ada, pengamatan, pola investigasi, serta kemampuan untuk menghubungkan peristiwa-peristiwa yang terjadi di masyarakat; dan umumnya digunakan untuk mengukur hasil belajar tingkat tinggi, seperti analisis, sintesis, dan evaluasi. Demikian pula jika dilihat dari hasil belajar yang diukur, bentuk tes pilihan ganda biasa sangat efektif untuk mengukur kemampuan kognitif tingkat rendah, efektif untuk mengukur kemampuan kognitif tingkat sedang, dan kurang efektif untuk mengukur kemampuan kognitif tingkat tinggi; sebaliknya, bentuk tes pilihan ganda analisis kasus kurang efektif untuk mengukur kemampuan kognitif rendah, efektif untuk mengukur kemampuan kognitif sedang, dan sangat efektif untuk mengukur kemampuan kognitif tingkat tinggi.

Beberapa karakteristik bentuk tes pilihan ganda biasa dan pilihan ganda analisis kasus seperti dijelaskan di atas jika dihubungkan dengan karakteristik siswa yang memiliki kemandirian belajar tinggi, sedang, dan rendah; maka dapat dijelaskan bahwa pemberian kedua bentuk tes tersebut kepada siswa yang memiliki kemandirian belajar yang berbeda terbukti dapat memberikan hasil yang berbeda pula. Siswa yang memiliki kemandirian belajar tinggi memperoleh hasil yang lebih tinggi pada semua bentuk tes dibandingkan dengan siswa yang memiliki 
kemandirian belajar sedang dan rendah. Temuan ini merupakan suatu bukti empiris bahwa tes pilihan ganda analisis kasus dapat memberikan nilai umpan balik yang lebih kaya bagi siswa, dan dapat meningkatkan kinerja belajar siswa, yang selanjutnya bermuara pada peningkatan hasil belajar yang optimal.

\section{SIMPULAN}

Penelitian ini membuktikan bahwa baik ragam bentuk tes maupun kemandirian belajar memberi pengaruh nyata terhadap hasil belajar siswa. Berkaitan dengan hal tersebut, maka upaya meningkatkan pengetahuan dan kemampuan guru dalam menyusun butir soal tes yang memiliki kemampuan mengukur handal dan sesuai dengan karakteristik keilmuan Sosiologi perlu terus dilatihkan. Pengukuran dan penilaian dalam pembelajaran perlu terus dikonstruksi ulang agar mampu menentukan evaluasi yang tepat dan memberikan umpan balik yang positif bagi siswa. Demikian pula dengan siswa peserta tes yang hampir memiliki ciri-ciri sama, menjadi permasalahan yang perlu diperhatikan jika bentuk tes yang diberikan tidak pernah mengalami perubahan dan konstruksi ulang.

Pengukuran hasil belajar tidak terpisahkan dari alat ukur apa yang dipakai untuk mengukur kemampuan minimal yang dikuasai siswa setelah mengikuti serangkaian proses pembelajaran berdasarkan kurikulum yang ditetapkan. Alat ukur berupa tes pilihan ganda merupakan alat ukur yang paling sering digunakan di sekolah dibandingkan dengan alat ukur yang lainnya, karena tes pilihan ganda di samping memiliki kelemahan, akan tetapi juga memiliki keunggulan yang lebih menguntungkan dibanding alat ukur lainnya. Mengacu pada hal tersebut di atas, terutama untuk menyesuaikan butir tes dengan karakteristik mata pelajaran yang akan diujikan, maka pemberian tes 
bentuk pilihan ganda analisis kasus dapat diterapkan di sekolah baik dalam hal tes harian, tes formatif, maupun dalam tes sumatif; tentunya dengan mengutamakan keterlibatan siswa dalam memecahkan berbagai masalah yang ditemukan dalam materi pembelajaran Sosiologi. Bentuk tes pilihan ganda analisis kasus menghendaki siswa untuk melibatkan pemikiran secara deduktif dan induktif, kemampuan analisis berdasarkan fenomena yang ada, pengamatan, pola investigasi, serta kemampuan untuk menghubungkan peristiwaperistiwa yang terjadi di masyarakat

\section{UCAPAN TERIMA KASIH}

Penulis mengucapkan terima kasih kepada berbagai pihak yang telah membantu penelitian ini. Penulis juga mengucapkan terima kasih kepada dewan redaksi Jurnal Socia atas kesempatan yang diberikan sehingga paper ini dapat diterbitkan pada Jurnal Socia edisi Juni 2016.

\section{DAFTAR PUSTAKA}

Anonim. 2010. Analisis Variansi Terapan. Modul Praktikum. Yogyakarta: Universitas Gadjah Mada, F.MIPA Jurusan Matematika, Laboratorium Komputasi Matematika dan Statistika.

Asmin. 2006. "Pengaruh Ragam Bentuk Tes Objektif dan Gaya Berpikir terhadap Fungsi Informasi Butir Tes: Penelitian Quasi Eksperimental dengan Analisis Item Response Theory di SMU DKI Jakarta". Jurnal Pendidikan dan Kebudayaan. Tahun ke-12 No. 062.

Azwar, Saifuddin. 2007. Test Prestasi: Fungsi dan Pengembangan Pengukuran Prestasi Belajar. Yogyakarta: Liberty.

Hamalik, Oemar. 2008. Perencanaan Pengajaran 
Berdasarkan Pendekatan

Sistem. Jakarta: Bumi Aksara.

Mulyasa. 2010. Implementasi

Kurikulum Tingkat Satuan

Pendidikan: Kemandirian

Guru dan Kepala Sekolah.

Jakarta: Bumi Aksara.

Sugilar. 2000. “Kesiapan Belajar Mandiri Peserta Pendidikan Jarak Jauh". Jurnal Pendidikan Terbuka dan
Jarak Jauh. 1 (2). Jakarta: Universitas Terbuka.

Surya, Hendra. 2007. Percaya Diri Itu Penting: Peran Orang Tua dalam Menumbuhkan Percaya Diri Anak. Jakarta: PT Elex Media Komputindo.

Zainul, Asmawi dan Nasution, Noehi. 2005. Penilaian Hasil Belajar. Jakarta: PAU-PPAIUT 